Y.Y. Khamza, Master Student

E-mail: erlan.hamza@mail.ru

ORCID ID: 0000-0003-2368-7485

B.U. Yerkebaeva, Candidate of Technical Sciences

Kazakh National Research Technical University after K. I. Satpayev

Almaty, the Republic of Kazakhstan

\title{
COMPARISON OF THE QUALITY-PRICE RATIO OF MODERN THERMAL INSULATION MATERIALS
}

\begin{abstract}
Today for a construction combination of availability, environmental friendliness, ease of installation and thermal conductivity of heat insulators are very important. In this article that kind of materials are considered. The main function of the heat-insulating material is to prevent heat loss from the insulated space. The transfer of heat is caused by the movement of molecules, which can not be stopped completely, but can be reduced. This property was taken as the basis for the production of heatinsulating materials, which are air packed in various ways: in pores, cells, capsules.
\end{abstract}

Keywords: heat-insulating materials, organic materials, efficient, heater, heat loss, foam, wool.

The purpose of the work is to study the market of heat-insulating materials, their applicability for the insulation of various structures.

Heat insulation materials are used to reduce heat losses, to create a comfortable climate in the premises, to reduce the cost of heating as well as the weight of building structures.

With the development of civilization, when the struggle for heat ceased to be so acute, massive fires and furnaces were replaced by central heating batteries, and new heat insulation materials replaced the sod, moss, felt and pakl. However, even now the problem of saving heat remains acute. There are several reasons. To heat hundreds of millions of square meters of poorly insulated homes, it is necessary to spend huge money on fuel and the reserves of its fossil are not infinite. Therefore, we have to look for new efficient materials and methods of thermal insulation. Today, modern materials and technologies are used in construction, which make it possible to conserve heat more efficiently. To choose the right thermal insulation material, you need to know what we want to achieve and for what purposes we need it. For this let us consider some of these materials in more detail.

The most common thermal insulation materials are:

- polystyrene foam insulation is a plastic type. The composition includes: polyester, water, emulsifiers and diisocyanate. The structure is cellular, consisting of $90 \%$ of the gaseous substance. Two versions of liquid polyurethane foam are produced: with open and closed voids. What is reflected in such indicators of insulation as density, strength, water absorption, vapor permeability and thermal conductivity.

Closed-cell polyurethane foam is used more in construction works, its density reaches 80 $\mathrm{kg} / \mathrm{m}^{3}$. The coefficient of thermal conductivity is $0.019-0.041 \mathrm{~W} /(\mathrm{m} \cdot \mathrm{K})$. Moisture absorption is low.[1]

- extruded polystyrene foam is synthetic thermal insulation material. Extrusion expanded polystyrene has a wide scope of application: thermal insulation of foundations and basements, laminated masonry and plaster facade, roofing. Extruded polystyrene foam and polystyrene foam consist of one substance, but differ in the technology of making granules.

Technical science heat materials
Materials of International Practical Internet Conference "Challenges of Science" 
Extruded polystyrene foam has low thermal conductivity (0.029-0.034), minimal water absorption $(0.2-0.4 \%)$. In terms of insulation and lightness, extruded polystyrene foam is superior to regular polystyrene $\left(40 \mathrm{~kg} / \mathrm{m}^{3}\right)$, which has a thermal conductivity of $0.038 \mathrm{~W} /(\mathrm{m} \cdot \mathrm{C})$. Tests prove that a heater made of expanded polystyrene is able to maintain its thermal and physical properties even when it is subjected to multiple freezing and thawing.[1]

- foam insulation - liquid urea-formaldehyde foam is obtained as a result of mixing polymer urea resin, foaming agent, orthophosphoric acid and water. The thermal conductivity is $0.028-0.041 \mathrm{~W} /(\mathrm{m} \cdot \mathrm{K})$. It has good vapor permeability. Not combustible, it melts under high temperatures, but is not toxic. Foam well fills the irregularities and voids inside the masonry, and does not expand. Due to the open porous structure it removes water vapor from the heated room, but requires reliable protection from moisture. It is an environmentally friendly material. Stacks to chemical and biological effects.

- mineral wool - material that is $80 \%$ composed of recycled paper, $8 \%$ of antiseptic (boric acid) and $12 \%$ of fire retardant (borax). Thanks to the latest ecowool does not burn, it does not have rodents and mold. The coefficient of thermal conductivity is $0.032-0.041 \mathrm{~W} /(\mathrm{m} \cdot \mathrm{K})$. The density is from 42 to $75 \mathrm{~kg} / \mathrm{m}^{3}$. Very high sound absorption characteristics. Low air permeability. Ecologically clean, non-toxic, safe for health heater. [2]

- stone wool is produced from the diabase rock by melting and converting the liquid mass into fibers. Such material is $99 \%$ air and only $1 \%$ rock. Used for insulation of walls and other structures everywhere. The main distribution of stone wool received as a heater for enclosing structures of buildings (facades, roofing). Due to the thermal insulation abilities, the material allows to prevent heat loss through the surfaces during the cold season and to keep the room cool during the warm period of the year.

Stone wool does not burn, but at a temperature of 600-700 degrees it decomposes forming hot dust. The coefficient of thermal conductivity of rock wool is in the range of 0.035 $0.039 \mathrm{~W} /(\mathrm{m} \cdot \mathrm{K}$.$) . Products can be produced with a coating of aluminum foil, kraft paper,$ fiberglass, etc.

- perlite - volcanic origin. Perlite is characterized by a fine concentric-shell-like individuality (perlite structure), along which it breaks down into rounded nuclei (pearls). Expanded perlite is a loose, porous, friable, lightweight, durable material. Fire-resistant: application temperature - from minus 200 to $900{ }^{\circ} \mathrm{C}$. It has heat and sound insulation properties, high absorbency: it can absorb fluids up to $400 \%$ of its own weight.

Perlite can be used in a natural way (in construction), but more commonly used expanded perlite. The use of expanded perlite in construction allows to increase the characteristics of heat, sound insulation and fire safety of erected structures, while significantly reducing the weight and volume of structures.

- foam glass is a foamed glass heat-insulating material. Today the main technology of production of foam glass is the so-called "Powder": silicate glass is mixed with a blowing agent. Foam glass is produced in the form of blocks, slabs, gravel and granules. The density of foam glass is $110-200 \mathrm{~kg} / \mathrm{m}^{2}$. The thermal conductivity of foamed glass is $0.04-0.08 \mathrm{~W} /(\mathrm{m} \cdot \mathrm{K})$. [3]

Along with excellent thermal insulation properties and full ecological and hygienic safety, foam glass has high strength, incombustibility, ease of processing and ease of installation, the ability to keep these indicators for a long time. The material is resistant to all commonly used acids and their vapors, does not allow water and steam to pass through. Foam glass is used mainly as a universal heat insulator: in a building complex; housing and communal complex; in agriculture; power engineering; mechanical engineering; chemical and petrochemical industries; food; paper; pharmaceutical and other industries.

Technical science heat materials
Materials of International Practical Internet Conference "Challenges of Science" 
Comparison of the materials on their thermal conductivity and the price for the insulation

\begin{tabular}{|c|c|c|c|}
\hline Name & Density, $\mathrm{kg} / \mathrm{m}^{3}$ & Price, $\operatorname{tg} / \mathrm{m}^{2}$ & $\begin{array}{c}\text { Thermal conductivity, } \\
W /(m \cdot K)\end{array}$ \\
\hline Polystyrene foam & $15-45$ & 1200 & $0,019-0,041$ \\
\hline $\begin{array}{l}\text { Extruded } \\
\text { polystyrene foam }\end{array}$ & $25-47$ & 1500 & $0,028-0,034$ \\
\hline Foam insulation & $5-35$ & 500 & $0,028-0,043$ \\
\hline Mineral wool & $12-35$ & 500 & $0,032-0,041$ \\
\hline Stone wool & $30-200$ & 550 & $0,030-0,039$ \\
\hline Perlite & $45-200$ & 2250 & $0,025-0,048$ \\
\hline Foam glass & $110-200$ & 2400 & $0,045-0,07$ \\
\hline
\end{tabular}

Results - materials were evaluated by the coefficient of thermal conductivity, the applicability of materials for the insulation of various structures.

Conclusions - we presented the table of comparison of the materials on their thermal conductivity and the price for the insulation. The quality - price ratio is very clearly expressed the better the material, the more expensive it is. You need ways to reduce the price and make it more affordable or improve other existing ones. It is impossible to choose the best thermal insulation material. All of them are more or less good for specific purposes. The choice depends on the thermal insulation properties and on personal preferences and financial possibilities.

As you can see, all materials are presented in the article is good on its place: some are better used for warming walls, others are floors, others are attics and roofs. Even for the device of thermal insulation inside the building or outside, different materials are suitable.

\section{References}

1. Строительство и техногенная безопасность / Construction and industrial safety ISSN 2413-1873.

2. Isover, 2018. Renovatie en na-isolatie. [online] Isover. Available at: $<$ http://www.isover.nl/documentatieservice/themabrochures/renovatie-en-na-isolatie/broc hure-renovatie-en-na-isolatie.pdf> [Accessed: 16 May 2018].

3. The Architects Journal https: //www.architectsjournal.co.uk

Technical science heat materials
Materials of International Practical Internet Conference "Challenges of Science" 